\title{
Instrumental seismic catalogue of Mt. Etna earthquakes (Sicily, Italy): ten years (2000-2010) of instrumental recordings
}

\author{
Salvatore Alparone, Vincenza Maiolino, Antonino Mostaccio, Antonio Scaltrito, \\ Andrea Ursino ${ }^{\star}$, Graziella Barberi, Salvatore D’Amico, Giuseppe Di Grazia, \\ Elisabetta Giampiccolo, Carla Musumeci, Luciano Scarfi, Luciano Zuccarello
}

Istituto Nazionale di Geofisica e Vulcanologia, Osservatorio Etneo, Sezione di Catania, Italy

\author{
Article history \\ Received May 15, 2014; accepted June 8, 2015. \\ Subject classification: \\ Volcano monitoring, Seismological data, Surveys, Instrumental seismic catalogue.
}

\begin{abstract}
Instrumental seismic catalogues are an essential tool for the zonation of the territory and the production of seismic hazard maps. They are also a valuable instrument for detailed seismological studies regarding active volcanoes and, above all, for interpreting the magma dynamics and the evolution of eruptive phenomena. In this paper, we show the first instrumental earthquake catalogue of Mt. Etna, for the period 2000-2010, with the purpose of producing a homogeneous dataset of 10 years of seismological observations. During this period, 16,845 earthquakes have been recorded by the seismic network run by the Istituto Nazionale di Geofisica and Vulcanologia, Osservatorio Etneo, in Catania. A total of 6,330 events, corresponding to approximately $40 \%$ of all earthquakes recorded, were located by using a one-dimensional $V_{P}$ velocity model. The magnitude completeness of the catalogue is equal to about 1.5 for the whole period, except for some short periods in 2001 and 2002-2003 and at the end of 2009. The reliability of the data collected is supported by the good values of the main hypocentral parameters through the time. The spatial distribution of seismicity allowed the highlighting of several seismogenetic areas characterized by different seismic rates and focal depths. This seismic catalogue represents a fundamental tool for several research aiming to a better understanding of the behavior of an active volcano such as Mt. Etna.
\end{abstract}

\section{Introduction}

Mt. Etna is one of the most active volcanoes in the world and, for this reason, it is considered by the scientific international community as one of the most intriguing natural laboratories for the understanding of eruptive processes and magma uprising. It is located in eastern Sicily (southern Italy), in a region of great geological and structural complexity, where the Maghrebian Chain, the Hyblean Foreland and the extensional features of the western boundary of the Ionian basin are identified (Lentini et al. [1994], Faccenna et al. [2001], Catalano et al. [2008]; see inset in Figure 1). The tectonic setting of Mt. Etna area results from a complex interaction between regional stress, gravity forces and dikeinduced rifting [Borgia et al. 1992, Lo Giudice and Rasà 1992, Monaco et al. 1997, Borgia et al. 2000, Neri et al. 2004, Walter et al. 2005].

In this framework, the major regional structural lineaments play a key role in the dynamic processes of the volcano [Bonaccorso et al. 1996, Gresta et al. 1998]. These lineaments, which mostly coincide with two regional structural trends (NE-SW and NNW-SSE), are recognized also within the volcanic edifice and are hypothesized to be the main seismogenic structures (Bo-

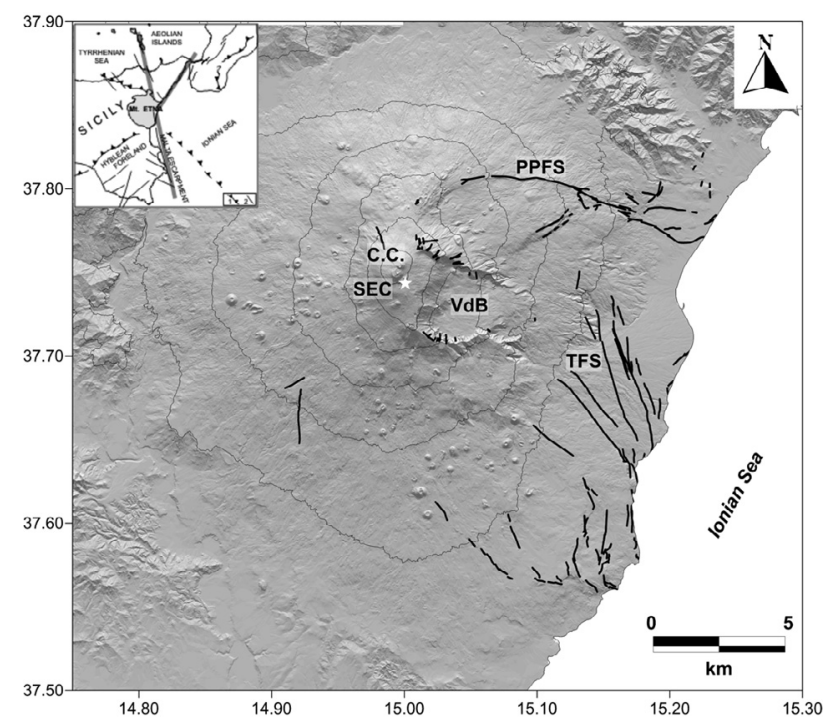

Figure 1. Schematic map of the main faults on Mt. Etna (modified from Azzaro et al. [2012]). In the inset: tectonic setting and main geological units of eastern Sicily and southern Calabria; grey lines indicate the main regional structural lineaments. PPFS = Pernicana Provenzana Fault System; C.C. $=$ Central Craters; SEC $=$ South East Crater; TFS $=$ Timpe Fault System; VdB = Valle del Bove. 
naccorso et al. [1996], Gresta et al. [1998]; Figure 1). In addition, Mt. Etna is characterized by many active tectonic structures, mostly located in the eastern and south-eastern flanks of the volcano, also near intensely urbanized areas, both with surface evidences (e.g. Provenzana Pernicana Fault System (PPFS), Timpe Fault System (TFS); Azzaro et al. [2012]; Figure 1) and buried faulting. Looking at the seismicity of the volcano, it is characterized by a high rate of earthquakes of low and moderate energy; sometimes it occurs in form of swarms rather than with a mainshock-foreshock distribution [Patanè et al. 2004]. Owing to the shallowness of the source, the most energetic events caused in the past severe damages to towns nearby the epicentral area [Azzaro 2004, Patanè et al. 2004].

In the considered time interval (2000-2010), different kinds of volcanic activity have characterized the volcano [Allard et al. 2006]. In 2000 a series of 66 parox-

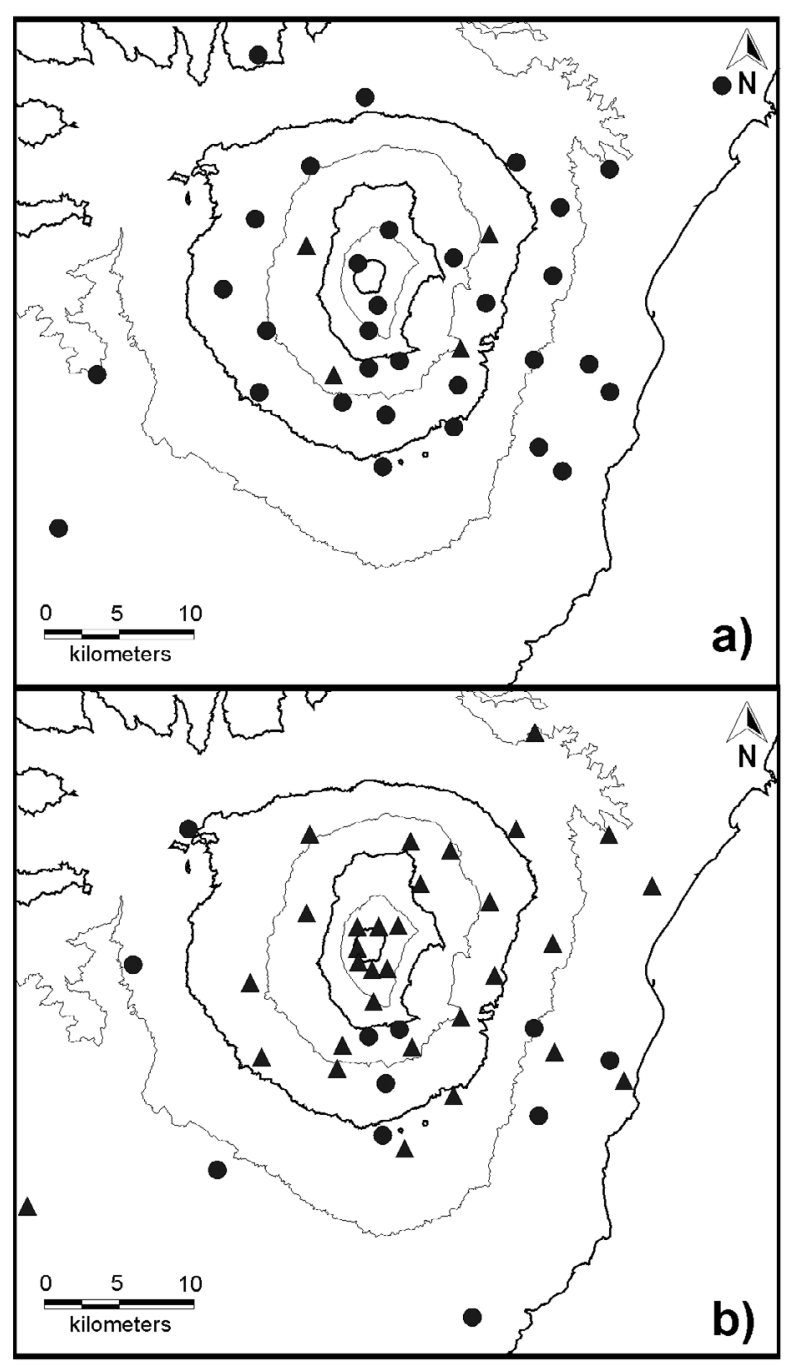

Figure 2. Two seismic network configuration over the time: (a) Poseidon Project (1994-2000); (b) Istituto Nazionale di Geofisica e Vulcanologia - Osservatorio Etneo - Sezione di Catania (INGV-OE; 2001- present day). Black dots and triangles indicate one and three component seismic stations, respectively. ysmal eruptive episodes occurred at the South-East Crater (SEC) with fire-fountains and eruption columns and extensive lava flows [Alparone et al. 2003]. Subsequently, two highly explosive and destructive flank eruptions took place in 2001 [Behncke and Neri 2003] and 2002-2003 [Andronico et al. 2005] in the southern and northeastern flanks of the volcano, followed by a passive flank eruption in 2004-2005 [Burton et al. 2005]. The 2006 was marked by the reactivation of the SouthEast Crater (SEC) with lava flow effusions and a vigorous Strombolian activity [Behncke et al. 2008, Andronico et al. 2009, Behncke et al. 2009]. In the 2008 a new eruption initiated with a system of eruptive fissures propagating SE from the summit craters toward the western wall of the Valle del Bove (VdB) [Cannata et al. 2009, Bonaccorso et al. 2011].

From the seismological point of view the most relevant energy releases occurred during the eruption of July 2001, during the eruption of October 2002 and on December 2009 during an important seismic sequence occurred in the northwestern side of the volcano.

Usually, local networks cover areal dimensions that do not exceed a few hundred square kilometers, with distance between stations of few kilometers. In active volcanoes, local seismic networks are of great importance since they provide the opportunity to extend the capacity of detection, and consequently of the location, of low magnitude seismic events and, therefore, to increase considerably the resolving power of the seismic network [Gambino et al. 2009, Rapisarda et al. 2009, Moretti et al. 2010, Castellano et al. 2012]. Indeed, the detection capability of a network depends on the density and distribution of seismic stations, from their site conditions, recording characteristics and from their data link to the processing center.

Earthquake catalogues are one of the most important products that seismic networks provide to the scientific community and society. A good earthquake catalogue is the first step to any seismotectonic study and hazard assessment analysis. In Italy, both historical [Rovida et al. 2011] and instrumental catalogues [Amato et al. 1997, CSTI 1.0 Working Group 2001, Chiarabba et al. 2005, Castello et al. 2006] have been of fundamental importance for a better understanding of the geodynamic processes of the Italian region. Regarding Mt. Etna volcano, a first catalogue, which lists 1,055 seismic events with $\mathrm{Md} \geq 2.5$ in the 1988-2001 time interval, is reported in Patanè et al. [2004].

In this study, we present the first instrumental seismic catalogue of Mt. Etna seismicity (2000-2010 time period) resulting from the monitoring activities of the Istituto Nazionale di Geofisica e Vulcanologia, Osservatorio Etneo (INGV-OE). This catalogue is the result 
of a scientific working group that daily analyzes and locates the earthquakes occurring in Mt. Etna area, providing detailed information on the spatial and temporal evolution of seismicity [Gruppo Analisi Dati Sismici 2015]. It is worth to highlight that a $1 \mathrm{D}$ velocity model has been used since this catalogue has been framed on the basis of the format of the Italian seismicity catalogue [Castello et al. 2006]. As indeed reported by Chiarabba et al. [2005], a 1D crustal velocity model yields a very good match of arrival times after earthquake location.

This catalogue constitutes a valuable tool for the seismic zonation of the territory and for detailed seismological studies [e.g. Allard et al. 2006, Murru et al. 2007, Carbone et al. 2009, Traversa and Grasso 2010, Cannata 2012, Cannata et al. 2013, Scarfi et al. 2013, Sicali et al. 2014] aimed to the interpretation of the dynamics of the volcano (i.e. seismic tomography, stress and strain field computation, etc.) with particular regard to the most important volcanic eruptions. The importance and uniqueness of this catalogue, unlike other existing, is the massive presence of microseismicity which is essential to assess in detail the state of Mt. Etna volcano. Indeed, these seismic data are used in drawing up reports periodically and also during important seismic or volcanic events, in order to alert regional and national Civil Defense authorities, furnishing detailed analysis on the spatial and time evolution of seismic activity (earthquake locations, seismic strain release, earthquake rate, etc.), in real time or near real time [see Alparone et al. 2009].

\section{Monitoring network}

Systematic observations of seismic activity at Mt. Etna began in 1967, when one mechanical seismometer was permanently deployed in the southern flank of the volcano, ca. $7 \mathrm{~km}$ apart from the summit craters [Bottari and Riuscetti 1967]. Previous investigations were limited to macroseismic observations and analyses of seismograms registered by a mechanical instrument and then collected by the astronomical observatory operating at the University of Catania.

It is only from the early 1990's, thanks to the Istituto Internazionale di Vulcanologia (IIV-CNR) and the Poseidon Project, which merged into the Istituto Nazionale di Geofisica e Vulcanologia (INGV) in 2001, that seismic data have been available in digital format for a considerable number of stations, that increased in time as well as for three-component sensors (Figure 2a). In particular, starting from 2005 the technology of several stations was upgraded from analogic short period 1-component to digital broad-band 3-component. Today, the permanent seismic network, managed by Istituto Nazionale di
Geofisica e Vulcanologia Osservatorio Etneo - Sezione di Catania (INGV-OE), consists, in the Mt. Etna area, of about 50 stations equipped with broad band 3-component seismometers (Figure 2b). All the important improvements have made it possible to increase the ability to detect the seismicity, allowing recording and locating even low energy events (magnitude $\geq 1.0$ ).

\section{Data analysis}

Earthquake monitoring of Mt. Etna is performed not only by means of an automatic system of earthquakes location [Patanè and Ferrari 1999] designed for surveillance purpose, but also by off-line tasks operated by an expert scientific staff of analysts which daily recognizes, analyses and storages the seismic events occurred in the area of Mt. Etna volcano. In detail, the several different main tasks carried out by this scientific staff, with high precision and regularity, is shown in Figure 3. The elaboration begins with the visual inspection of the seismic signals continuously recorded by the

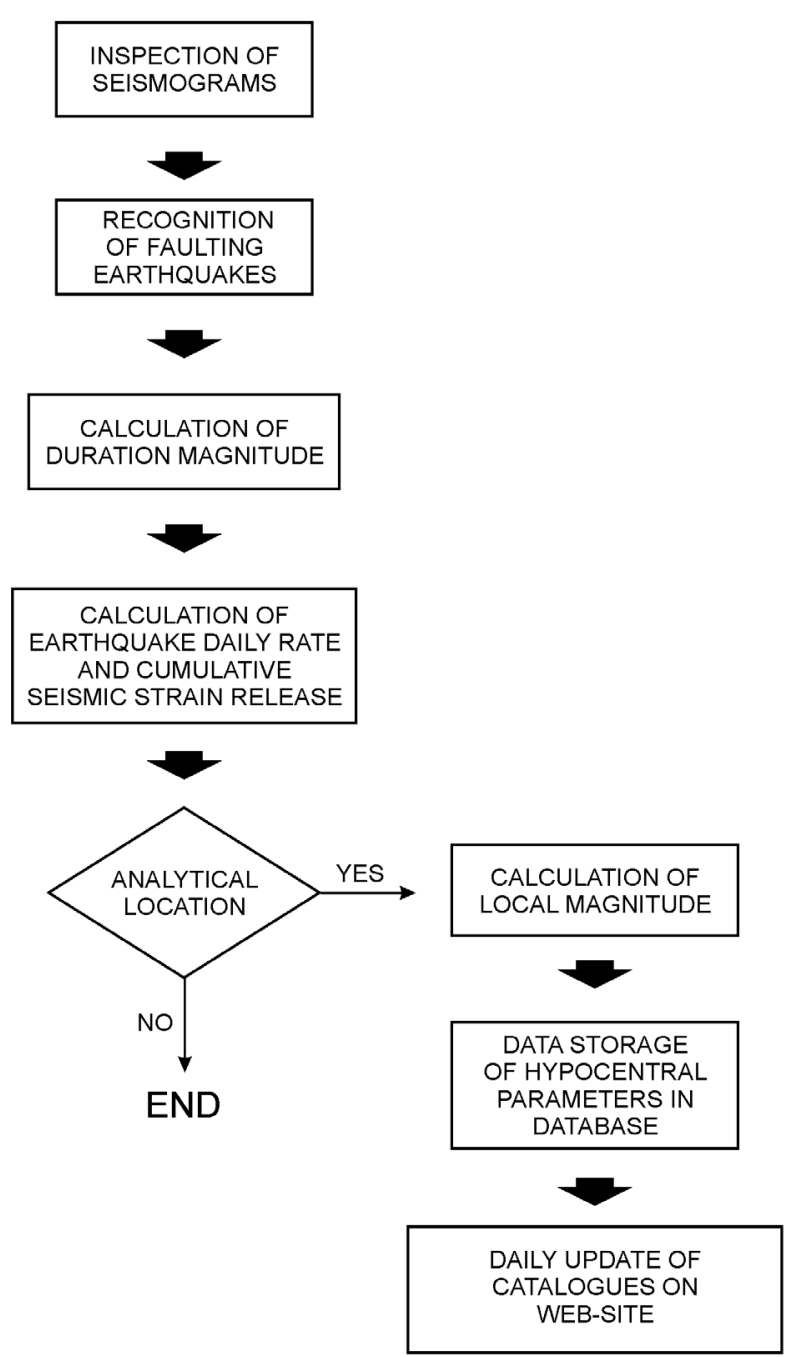

Figure 3. Flowchart of the routine analysis developed by the scientific staff for seismic monitoring of Mt. Etna volcano. 


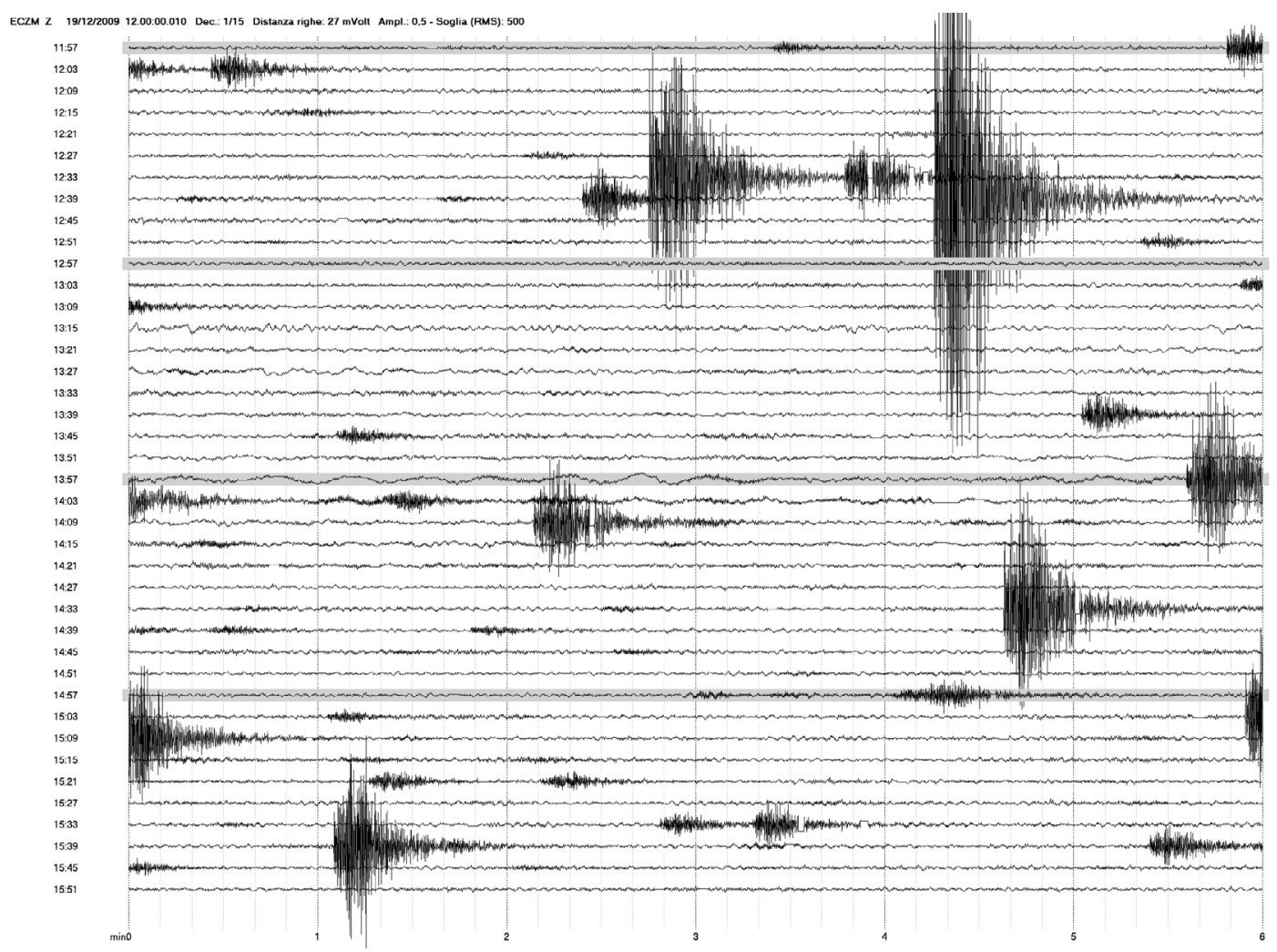

Figure 4. An example of bitmap that encompasses 4 hours of seismic signal, showing several earthquakes belonging to a seismic swarm.

permanent network focusing only on volcano-tectonic earthquakes [e.g. Patanè and Giampiccolo 2004]. To perform this task, seismic traces for selected stations are drawn in form of "virtual/digital" drum recorder and stored as bitmap (Figure 4). All local earthquakes recognized by visual inspection are classified by time of recording and duration magnitude and used to compute the earthquakes daily rate and the related seismic strain release. Finally, all the hypocentral parameters of earthquakes recorded at least at six stations are calculated and stored in the database of the INGV-OE (Figure 3; Gruppo Analisi Dati Sismici [2015]). Earthquakes daily rate and associated seismic strain release are reported in Figure 5. The magnitude of earthquakes is calculated using the duration of the seismic event ac-

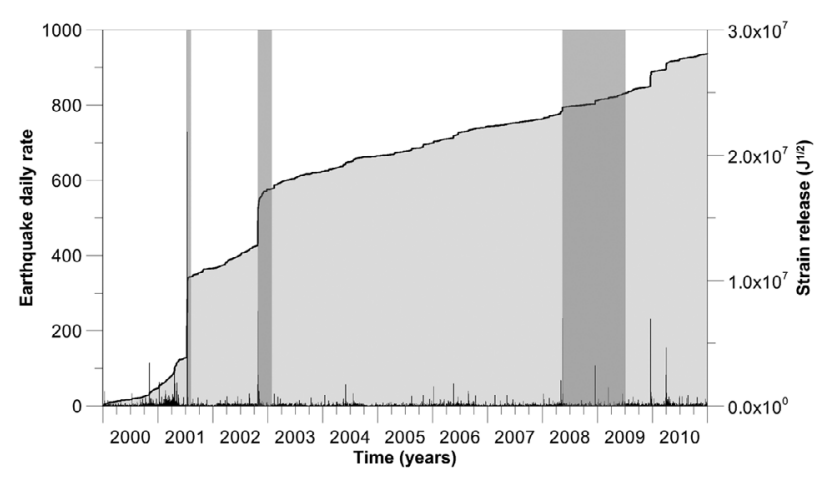

Figure 5. Daily earthquake occurrence and related cumulated strain release from 2000 to 2010 . The periods marked in dark gray indicate the main flank eruptions. cording to Caltabiano et al. [1986] relationship. The seismic energy $(\mathrm{E})$ in Erg is computed using the relationship $\log \mathrm{E}=9.9+1.9 \mathrm{M}-0.024 \mathrm{M}^{2}[$ Richter 1958]. The diagram (Figure 5) allows to highlight a background seismicity overlapping seismic swarms, some of them relevant both in number and energy released. These seismic swarms occur both in correspondence of eruptive phases (i.e. 2001, 2002-2003, 2008-2009) and during periods of normal background seismicity (2009, 2010; Figure 5).

Earthquakes are located using the Hypoellipse algorithm [Lahr 1989] and the 1D crustal velocity model proposed for Etna area by Hirn et al. [1991] and subsequently modified by Patanè et al. [1994]. Earthquakes with most of first arrivals picked at the summit stations, therefore falling within the volcanic edifice, were located setting the top of the velocity model at $1,600 \mathrm{~m}$ above the sea level. It is worth to highlight that only starting from 2005, due to the improvement of Mt. Etna seismic network and the installation of digital stations equipped with broad band three component sensors, it has also been possible to calculate the local magnitude by using the amplitude of the horizontal ground displacements of the earthquake [Richter 1935]. So, starting from 2005 two values of magnitude (in duration and local) are, usually, associated to each earthquake.

In the time period considered, 16,845 earthquakes have been recorded and only eight events have local magnitude greater than or equal to 4.0. We located 6,330 

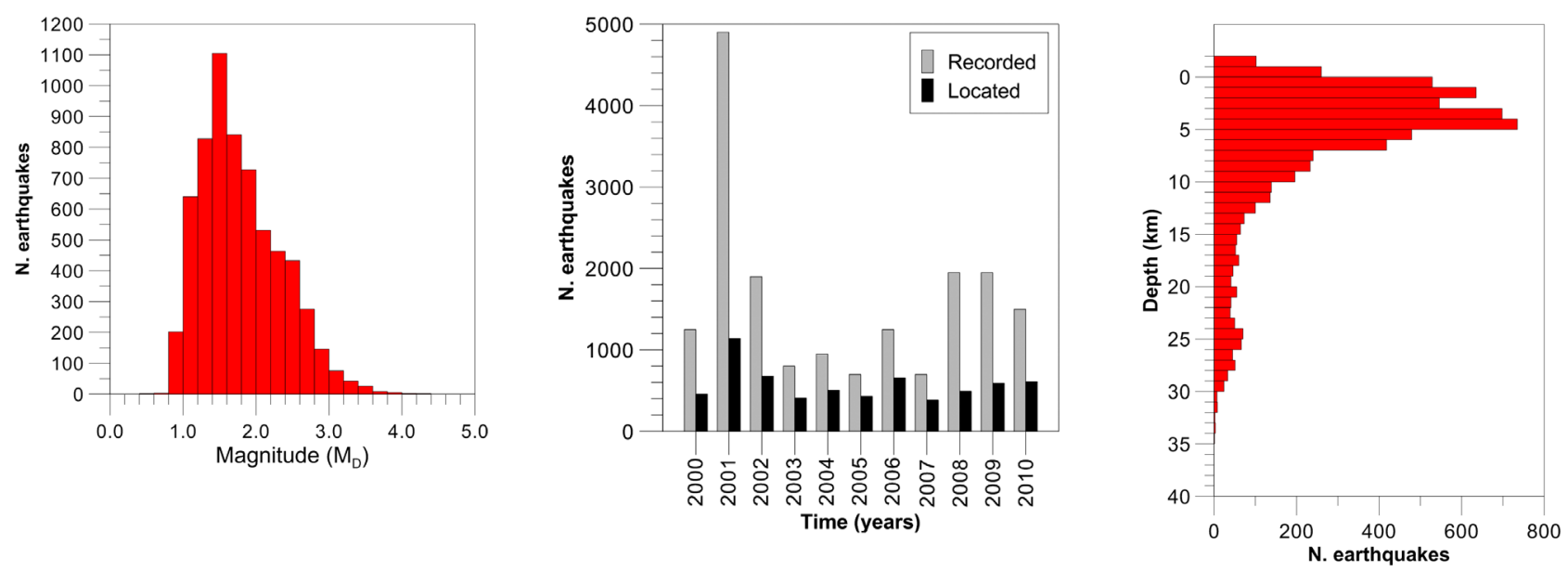

Figure 6 (left). Earthquakes number versus duration magnitude. Note the peak around the value 1.5. Figure 7 (center). In gray the number of earthquakes recorded by the seismic network in the time span 2000-2010. In black the number of localized events. Figure 8 (right). Frequency distribution of earthquakes with respect to depth.

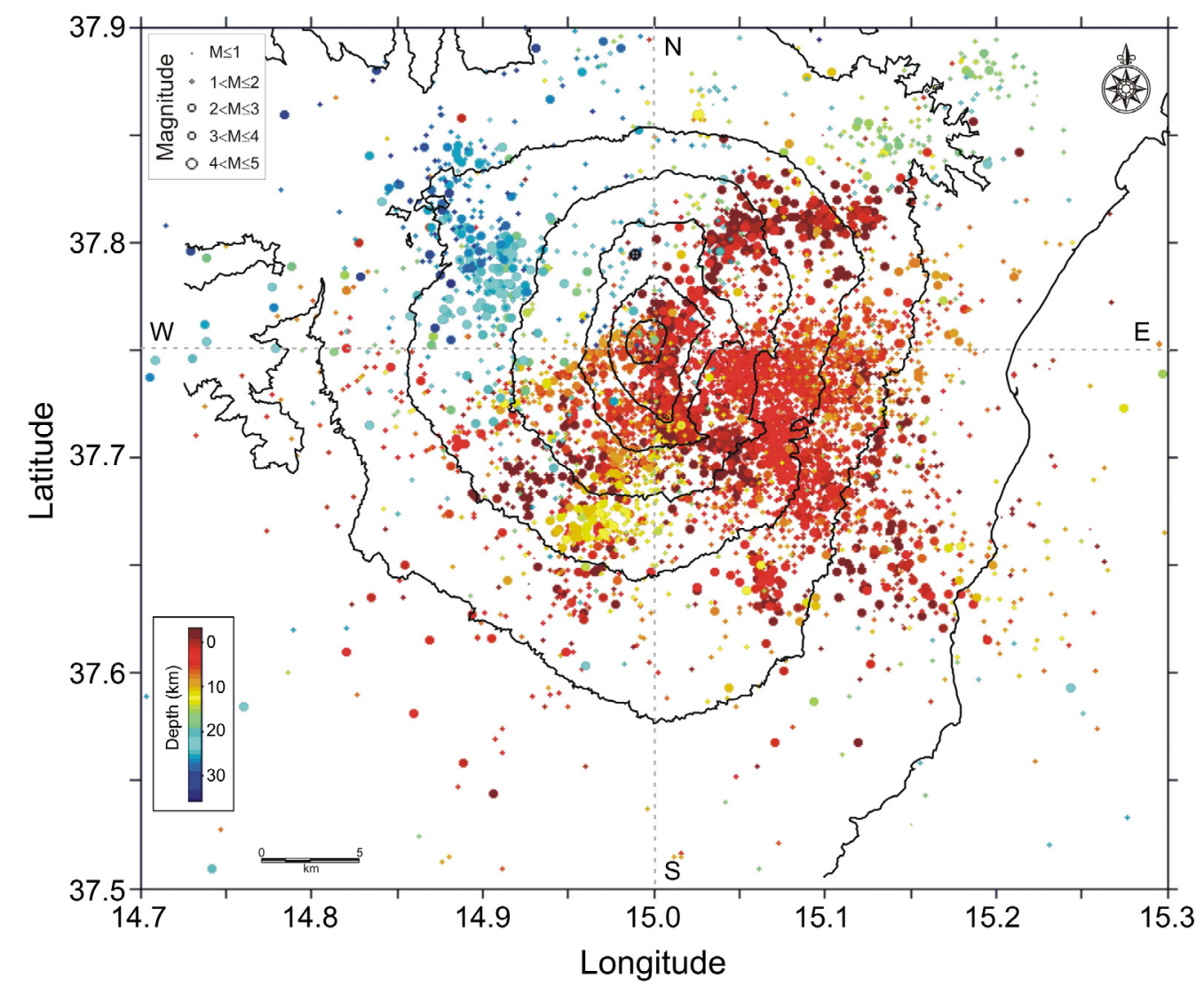

Figure 9. Epicentral map of earthquakes belonging to Mt. Etna seismic catalogue in the period 2000-2010. Circle size indicates magnitude, colors indicate range depth (see inset for details). N-S and E-W indicates the traces of the cross-sections (see Figure 10).

events ( $\sim 40 \%$ of total), falling in a geographic area with latitude between $37.50 \mathrm{~N}$ and $37.90 \mathrm{~N}$ and longitude from $14.70 \mathrm{E}$ to $15.30 \mathrm{E}$. The remnant $60 \%$ of recorded earthquakes was not located because: (i) many earthquakes are of low energy and recorded only at a few stations; (ii) a worse signal to-noise ratio, induced by the increase of volcanic tremor observed during Mt. Etna eruptions, obscures the first P-wave arrival; (iii) during the seismic swarms many events occur on the tail of the previous ones, not allowing to recognize properly the time arrival of P-phase.

About $37 \%$ of the located earthquakes has a magnitude less than or equal to 1.5 (Figure 6) with a maximum value of 4.8 observed in the north-western flank of the volcano (December 2009). Figure 7 shows the number of earthquakes recorded and localized in the time span 2000-2010 (on average 400-500 events for year are located). Only in 2001, the seismic rate is of about 1,100 earthquakes due to the great seismic swarm occurred during the onset of the eruption. 

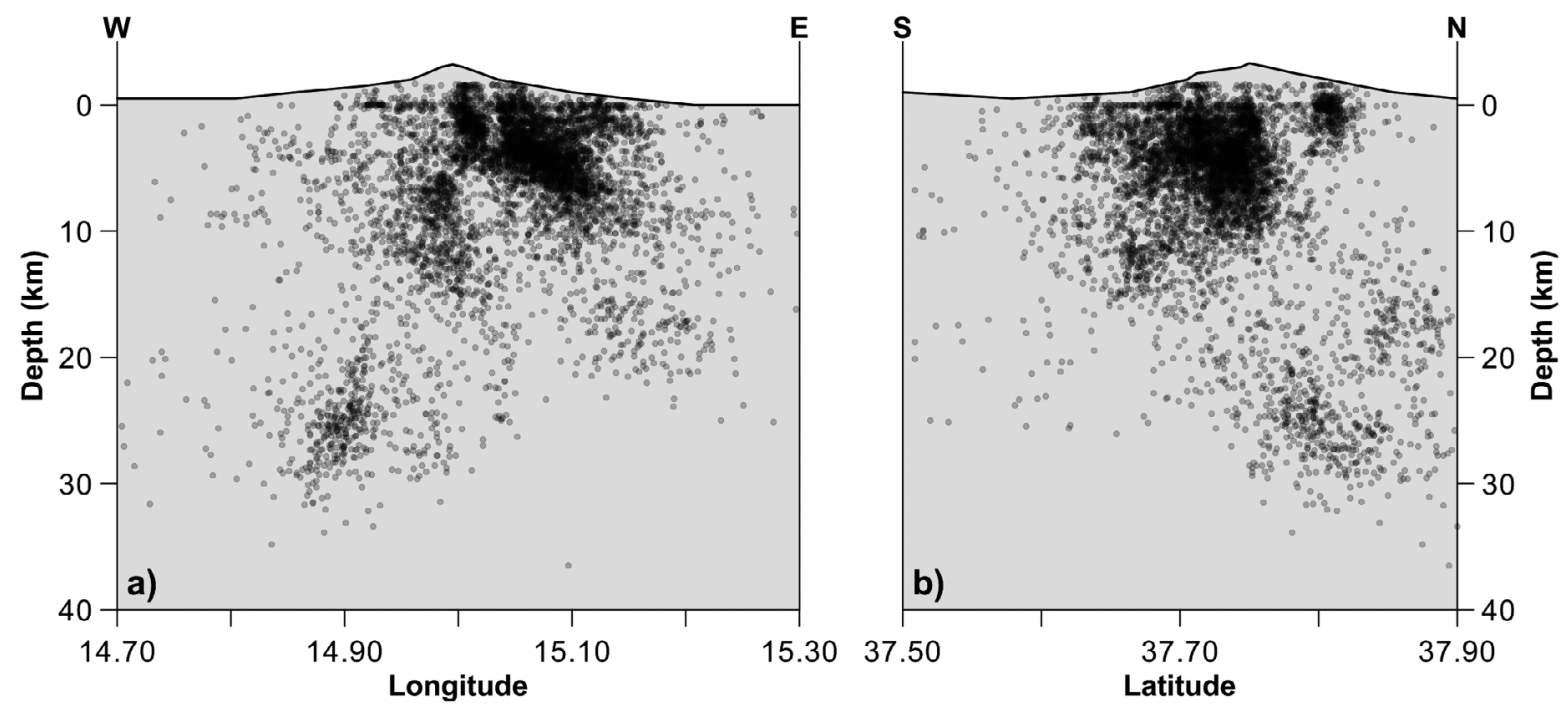

Figure 10. Cross-sections (E-W, Figure 10a; N-S, Figure 10b) of earthquakes showed in Figure 9.

According to Patanè et al. [2004], about $50 \%$ of Mt. Etna earthquakes are shallow (focal depth $<5 \mathrm{~km}$ b.s.l.) and mainly located in the eastern flank. As shown in Figure 8, the seismicity is present in a wide range of depth (up to $30 \mathrm{~km}$ ); however most of it is concentrated within the first $7 \mathrm{~km}$ depth.

The spatial distribution of seismicity evidences several seismogenetic volumes characterized by different seismic rates and focal depths. In the epicentral map (Figure 9) it is clear that the eastern sector is seismically very active and most of the seismicity is concentrated therein. The epicenters are concentrated in the northeastern flank, along the Provenzana Pernicana Fault System, in the Valle del Bove and in a wide sector to the ESE of the Valle del Bove (Figure 9). The main character clearly distinguishing the two flanks of the volcano is the depth of the focii (Figures 9-10). In fact, in the

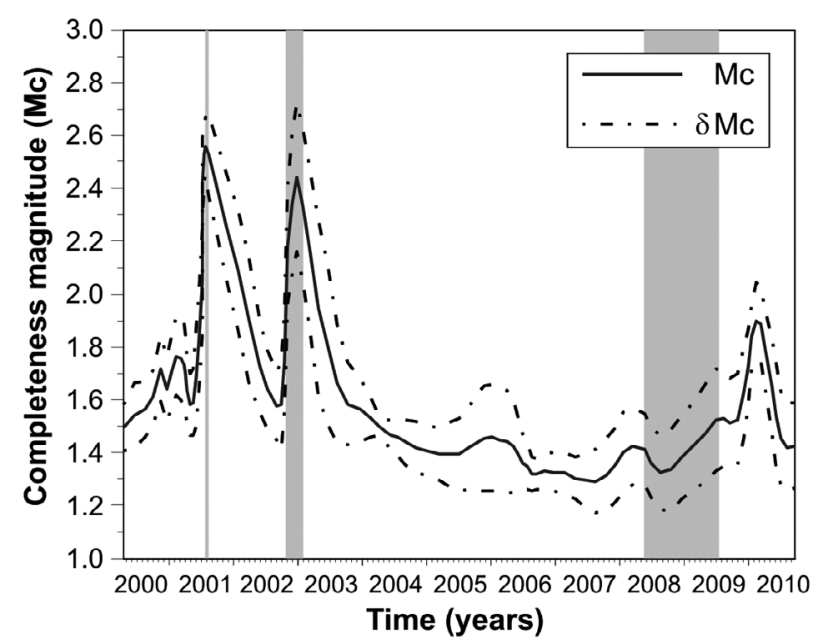

Figure 11. Temporal trend of completeness magnitude (Mc) during the 2000-2010 time span. The dashed line marks the standard deviation value of Mc. The periods marked in gray indicate the main flank eruptions. eastern sector most of earthquakes are located within $7 \mathrm{~km}$ of depth and, the deepening of focii towards east is evident (Figure 10a). Most of the epicenters are concentrated in the northeastern flank, along the Pernicana Fault System, in the Valle del Bove and in a wide sector to the ESE of the Valle del Bove (Figure 9). Conversely, in the southwestern flank the seismicity is distributed along a wide zone between the summit craters and the mid-southern flank of the volcano with hypocenters between 5 and $15 \mathrm{~km}$ of depth. The northwestern sector is typically characterized by the deepest seismicity of volcano with focii exclusively in the range 20-30 km of depth (Figures 9-10).

One of the most important parameter for the statistical analysis of seismicity is the completeness magnitude (Mc), useful to classify a catalogue as complete. In literature different techniques have been suggested to compute Mc [e.g., Rydelek and Sacks 1989, Ogata and Katsura 1993, Wiemer and Wyss 2000]. In the catalogue, Mc may change over the time, generally decreasing due to the improvements of the seismic stations and the evolution of recording technology, therefore it cannot be considered the same for the whole time period. Figure 11 shows Mc over the time calculated by using the ZMAP program developed by Wiemer [2001] and using a moving windows of 250 earthquakes overlapped by 4 . It is worth to highlight that $\mathrm{Mc}$ mean value remains about 1.5 for almost the whole period, except for the 2001 and 2002-2003 and at the end of 2009 (Figure 11). These results are in good agreement with those obtained by Murru et al. [2007] and Mantovani et al. [2012] who used Mt. Etna earthquakes in the period 1999-2005 and 1997-2011, respectively. The increase of completeness magnitude (Mc $\sim 2.5$ ) was observed in correspondence of the three very strong seismic swarms occurred at Mt. Etna during the onset of 2001 and 2002-2003 erup- 

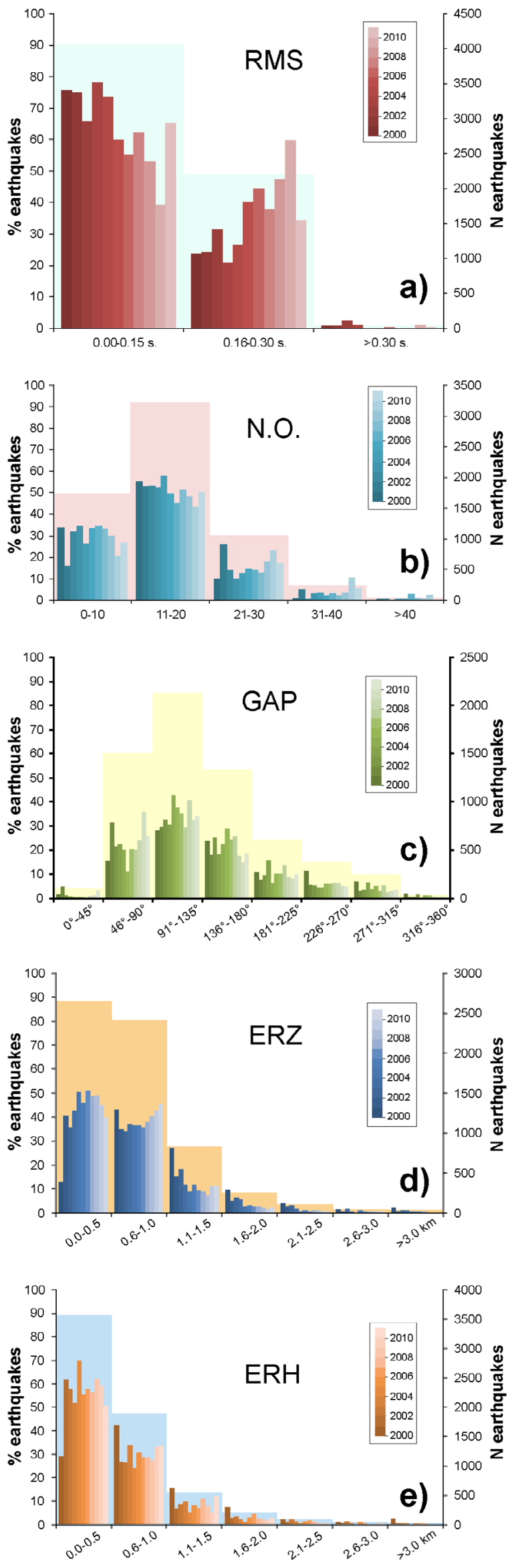

Figure 12. Temporal evolution of the hypocentral parameters associated to seismic location during the analyzed period: (a) RMS; (b) N.O.; (c) GAP; (d) ERZ; (e) ERH. See the text for further details. tions [Allard et al. 2006] and during the strong seismic sequence (Mc 2.0 ) occurred in 2009 in the north-western flank of the volcano [Alparone et al. 2010].

In order to verify the evolution of the quality of the main hypocentral parameters, we carried out their temporal evolution in the time span 2000-2010 (Figure 12). Nevertheless statistics on these parameters are obviously affected by earthquakes size (magnitude) and relative location respect to the seismic network. Hereafter some general remarks:

RMS (Root-mean-square travel-time residual (s) Figure 12a): it is noteworthy that the class most represented is in the range $0.00-0.15 \mathrm{~s}$ with maximum values within $0.3 \mathrm{~s}$.

NO (Total number of P- and S-phase used in the earthquake location - Figure 12b): the class most represented is in the range 11-20. Over time, the class 11-20 seems slightly decreasing, while the class represented by the interval 21-30 and 31-40 tends to increase.

GAP (largest azimuthal separation, in degrees, between stations as seen from the epicenter; Figure 12c): the class most represented is in the range $91^{\circ}-135^{\circ}$ while most of this value is within $180^{\circ}$. In particular, the classes $46^{\circ}-90^{\circ}$ and $91^{\circ}-135^{\circ}$ show an increasing trend over time, while the classes $226^{\circ}-270^{\circ}$ and $271^{\circ}-315^{\circ}$ show a stationary trend. In addition, since 2007 it is possible to observe a slight increase in class $136^{\circ}-180^{\circ}$.

ERZ (vertical location error in $\mathrm{km}$ - Figure $12 \mathrm{~d}$ ) and ERH (horizontal location error in $\mathrm{km}$ - Figure 12e): for both values, the class most represented is in the range $0.0-0.5 \mathrm{~km}$, while most of these values are in the range $0.0-1.0 \mathrm{~km}$. The error in the vertical coordinates (ERZ) increases, over time, in the range $0.6-1.0 \mathrm{~km}$. On the other hand, the error in the epicenter coordinates $(\mathrm{ERH})$ seems to maintain a stable value.

The state of this parameters (see over the time the increasing RMS values within the range 0.16-0.3 seconds, the GAP increasing trend in the lowest values and the increase error in the vertical coordinates ERZ) is closely related to the improving of the seismic network in quality and number of stations, which involved the use of more P and S-phases during the time interval considered.

\section{Concluding remarks}

An instrumental seismic catalogue is a fundamental tool for all research that aim to better understand the dynamics and evolution of an active volcano such as Mt. Etna.

The present seismic catalogue is the first complete instrumental catalogue at Mt. Etna during a 10 years period of observations (2000-2010) and it is the result of a scientific working group (analysts) that daily analyzes 
and locates the earthquakes occurring in the Mt. Etna area, providing detailed information on the spatial and temporal evolution of seismicity. The importance and uniqueness of this catalogue, unlike other existing, is the massive presence of microseismicity, essential to assess in detail the state of Mt. Etna volcano. Moreover, these seismic data, which fall in monitoring activities of INGV-OE, are usually used in drawing up periodic reports and also during important seismic or volcanic events in order to alert regional and national Civil Defense authorities.

Here the main features of the catalogue:

- 16,845 earthquakes have been recorded. About 6,330 seismic events have been located ( $\sim 40 \%$ of total). In particular, about $37 \%$ of the located earthquakes has a duration magnitude less than or equal to 1.5. In the analyzed period, only eight earthquakes with local magnitude greater than or equal to 4.0 were recorded, with the largest one $(\mathrm{Ml}=4.8)$ located in the north-western flank of the volcano (December 2009). The seismicity of the volcano is strongly characterized by seismic swarms, relevant both in number and energy released;

- all earthquakes were located using a 1D crustal velocity model;

- the spatial distribution of seismicity allowed to highlight several seismogenetic areas characterized by different seismic rates and focal depths;

- for the investigated period, we carried out the completeness magnitude $(\mathrm{Mc})$. It is almost always equal to 1.5 except in three periods where Mc reaches the value of 2.5 ;

- a time trend of the quality hypocentral location parameters is carried out. The good values allow us to affirm the high reliability of the seismic locations.

Our future aim is to adopt a location procedure, simple to use for monitoring purposes, which allows to overcome the limitations imposed by the use of less advanced algorithms. This catalogue will be also periodically updated in order to provide to the scientific community and to the society an useful and valuable tool to get a complete picture of the seismicity of this volcano. Data are freely available (see the Appendix).

Acknowledgements. The authors are indebted to the technicians of seismological staff of Istituto Nazionale di Geofisica e Vulcanologia - Osservatorio Etneo - Sezione di Catania for enabling the acquisition of seismic data and to Ferruccio Ferrari for providing the bitmap of seismic traces. A special thanks to Unità Funzionale Sala Operativa e Information Technology of Istituto Nazionale di Geofisica e Vulcanologia - Osservatorio Etneo - Sezione di Catania for informatic support. We thank the Editor Francesca Bianco, the Associate Editor Andrea Bizzarri and an anonymous referee for their constructive comments and suggestions which helped significantly improving the quality of the manuscript. Finally, we wish to thank Raffaele Azzaro who encouraged this work. This catalogue is part of INGV - Osservatorio Etneo - Sezione di Catania Database.

\section{References}

Allard, P., B. Behncke, S. D’Amico, M. Neri and S. Gambino (2006). Mount Etna 1993-2005: Anatomy of an evolving eruptive cycle, Earth-Sci. Rev., 78, 85-114.

Alparone, S., D. Andronico, L. Lodato and T. Sgroi (2003). Relationship between tremor and volcanic activity during the Southeast Crater eruption on Mount Etna in early 2000, J. Geophys. Res., 108; doi:10.1029/2002JB001866.

Alparone, S., G. Barberi, G. Di Grazia, E. Giampiccolo, V. Maiolino, A. Mostaccio, C. Musumeci, A. Scaltrito, L. Scarfi and A. Ursino (2009). Routine analysis for seismic monitoring of eastern Sicily (Italy), Conferenza A. Rittmann "La vulcanologia italiana: stato dell'arte e prospettive future", Nicolosi (Catania), June 11-13, p. 233; ISBN 978-88-89972-11-3.

Alparone, S., G. Barberi, G. Di Grazia, E. Giampiccolo, V. Maiolino, A. Mostaccio, C. Musumeci, A. Scaltrito, L. Scarfi and A. Ursino (2010). La sequenza sismica nel versante nord-occidentale dell'Etna del 19-27 Dicembre 2009: evidenze di ricarica magmatica profonda?, Convegno Nazionale GNGTS, Prato (Italy), October 26-28, 138-140.

Amato, A., C. Chiarabba and G. Selvaggi (1997). Crustal and deep seismicity in Italy, Annali di Geofisica, 40 (5), 981-993.

Andronico, D., S. Branca, S. Calvari, M. Burton, T. Caltabiano, R.A. Corsaro, P. Del Carlo, G. Garfi, L. Lodato, L. Miraglia, F. Murè, M. Neri, E. Pecora, M. Pompilio, G. Salerno and L. Spampinato (2005). A multidisciplinary study of the 2002-03 Etna eruption: insights into a complex plumbing system, B. Volcanol., 67, 314-330; doi:10.1007/s00445-004-0372-8.

Andronico, D., S. Scollo, A. Cristaldi and F. Ferrari (2009). Monitoring ash emission episodes at Mt. Etna: The 16 November 2006 case study, J. Volcanol. Geoth. Res., 180, 123-134; doi:10.1016/j.jvolgeores.2008.10.019.

Azzaro, R. (2004). Seismicity and active tectonics in the Etna region: constraints for a seismotectonic model, In: A. Bonaccorso, S. Calvari, M. Coltelli, C. Del Negro and S. Falsaperla (eds.), Mt. Etna: Volcano Laboratory, American Geophysical Union, 205-220.

Azzaro, R., S. Branca, K. Gwinner and M. Coltelli (2012). The volcano-tectonic map of Etna volcano, 1:100,000 scale: morphotectonic analysis from high-resolution DEM integrated with geologic, active faulting and seismotectonic data, Ital. J. Geosci. (B. Soc. Geol. Ital.), 131 (1), 153-170.

Behncke, B., and M. Neri (2003). The July-August 2001 eruption of Mt. Etna (Sicily), B. Volcanol., 65, 461476; doi:10.1007/s00445-003-0274-1.

Behncke, B., S. Calvari, S. Giammanco, M. Neri and H. Pinkerton (2008). Pyroclastic density currents result- 
ing from the interaction of basaltic magma with hydrothermally altered rock: An example from the 2006 summit eruptions of Mount Etna, Italy, B. Volcanol., 70, 1249-1268; doi:10.1007/s00445-008-0200-7.

Behncke, B., S. Falsaperla and E. Pecora (2009). Complex magma dynamics at Mount Etna revealed by seismic, thermal, and volcanological data, J. Geophys. Res., 114, B03211; doi:10.1029/2008JB005882.

Bonaccorso, A., F. Ferrucci, D. Patanè and L. Villari (1996). Fast deformation processes and eruptive activity at Mount Etna (Italy), J. Geophys. Res., 101, 17467-17480.

Bonaccorso, A., A. Bonforte, S. Calvari, C. Del Negro, G. Di Grazia, G. Ganci, M. Neri, A. Vicari and E. Boschi (2011). The initial phases of the 2008-2009 Mount Etna eruption: A multidisciplinary approach for hazard assessment, J. Geophys. Res., 116, B03203; doi: 10.1029/2010JB007906.

Borgia, A., L. Ferrari and G. Pasquarè (1992). Importance of gravitational spreading in the tectonic evolution of Mt. Etna, Nature, 357, 231-235; doi:10.10 38/357231a0.

Borgia, A., R. Lanari, E. Sansosti, M. Tesauro, P. Berardino, G. Fornaro, M. Neri and J.B. Murray (2000). Actively growing anticlines beneath Catania from the distal motion of Mount Etna's decollement measured by SAR interferometry and GPS, Geophys. Res. Lett., 27 (20), 3409-3412.

Bottari, A., and M. Riuscetti (1967). La stazione sismica di Serra La Nave sull'Etna, Annali di Geofisica, 20, 243-264.

Burton, M.R., M. Neri, D. Andronico, S. Branca, T. Caltabiano, S. Calvari, R.A. Corsaro, P. Del Carlo, G. Lanzafame, L. Lodato, L. Miraglia, G. Salerno and L. Spampinato (2005). Etna 2004-2005: an archetype for geodynamically-controlled effusive eruptions, Geophys. Res. Lett., 759 (32), L09303; doi:10.1029/2005GL022527.

Caltabiano, T., D. Condarelli, S. Gresta, D. Patanè and G. Patanè (1986). Analisi preliminare dei dati della stazione sismica di Serra Pizzuta Calvarina, CNR IIV Open File Rep. 10/86.

Cannata, A., P. Montalto, E. Privitera, G. Russo and S. Gresta (2009). Tracking eruptive phenomena by infrasound: May 13, 2008 eruption at Mt. Etna, Geophys. Res. Lett., 36, L05304; http:/ / dx.doi.org/10.10 29/2008GL036738.

Cannata, A. (2012). Crustal changes at Mt. Etna volcano accompanying the 2002-2003 eruption as inferred from repeating earthquake analysis, Geophys. Res. Lett., 39 L18311; doi:10.1029/2012GL053185.

Cannata, A., S. Alparone and A. Ursino (2013). Repeating volcano-tectonic earthquakes at Mt. Etna vol- cano (Sicily, Italy) during 1999-2009, Gondwana Research, 24 (2013), 1223-1236.

Carbone, D., S. D'Amico, C. Musumeci and F. Greco (2009). Comparison between the 1994-2006 seismic and gravity data from Mt. Etna: New insight into the long-term behavior of a complex volcano, Earth Planet. Sc. Lett., 279, 282-292.

Castellano, M., D. Galluzzo, M. La Rocca and M. Capello (2012). Lo studio dei vulcani attivi e delle strutture crostali con reti sismiche temporanee: storia, evoluzione e prospettive della Rete Sismica Mobile dell'Osservatorio Vesuviano (INGV), Quaderni di Geofisica, 97.

Castello, B., G. Selvaggi, C. Chiarabba and A. Amato (2006). CSI Catalogo della sismicità italiana 19812002 (versione 1.1. INGV-CNT, Roma).

Catalano, S., G. De Guidi, G. Romagnoli, S. Torrisi, G. Tortorici and L. Tortorici (2008). The migration of plate boundaries in SE Sicily: influence on the largescale kinematic model of the African promontory in southern Italy, Tectonophysics, 449, 41-62; doi:10. 1016/j.tecto.2007.12.003.

Chiarabba, C., L. Jovane and R. Di Stefano (2005). A new view of Italian seismicity using 20 years of instrumental recordings, Tectonophysics, 395 (3-4), 251-268.

CSTI 1.0 Working Group (2001). Catalogo strumentale dei terremoti italiani dal 1981 al 1996 (CD-ROM versione 1.0, Clueb Bologna).

Faccenna, C., T.W. Becker, F.P Lucente, L. Jolivet and F. Rossetti (2001). History of subduction and back-arc extension in the central Mediterranean, Geophys. J. Int., 145, 809-820; doi:10.1046/j.0956-540X.2001.01 435.x.

Gambino, S., L. Cammarata and S. Rapisarda (2009). High precision locations of long-period events at La Fossa Crater (Vulcano Island, Italy), Annals of Geophysics, 52 (2), 137-147.

Gresta, S., L. Peruzza, D. Slejko and G. Distefano (1998). Inferences on the main volcanotectonic structures at Mt. Etna (Sicily) from a probabilistic seismological approach, J. Seismol., 2, 105-116.

Gruppo Analisi Dati Sismici (2015). Catalogo dei terremoti della Sicilia Orientale - Calabria Meridionale (1999-2015), INGV, Catania; http:/ / www.ct.ingv.it/ ufs/analisti/catalogolist.php.

Hirn, A., A. Nercessian, M. Sapin, F. Ferrucci and G. Wittlinger (1991). Seismic heterogeneity of Mt. Etna: structure and activity, Geophys. J. Int., 105, 139-153.

Lahr, J.C. (1989). HYPOELLIPSE/VERSION 2.0*: A computer program for determining local earthquakes hypocentral parameters, magnitude, abd first motion pattern, U.S. Geol. Sur., Open File Rept., 89- 
116, $81 \mathrm{pp}$.

Lentini, F., S. Carbone and S. Catalano (1994). Main structural domains of the central mediterranean region and their tectonic evolution, B. Geofis. Teor. Appl., 36, 103-125.

Lo Giudice, E., and R. Rasà (1992). Very shallow earthquakes and brittle deformation in active volcanic areas: the Etnean region as example, Tectonophysics, 202, 257-268.

Mantovani, A., M.S. Barbano and S. D’Amico (2012). The $b$ value as a long term precursor of volcanic activity: a case study at Mt. Etna, Convegno Nazionale GNGTS, Potenza (Italy), November 20-22.

Monaco, C., P. Tapponnier, L. Tortorici and P.Y. Gillot (1997). Late Quaternary slip rates on the AcirealePiedimonte normal faults and tectonic origin of Mt. Etna (Sicily), Earth Planet. Sc. Lett., 147, 125-139.

Moretti, M., A. Govoni, G. Colasanti, M. Silvestri, E. Giandomenico, S. Silvestri, F. Criscuoli, L. Giovani, A. Basili, C. Chiarabba and A. Delladio (2010). La Rete Sismica Mobile del Centro Nazionale Terremoti, Rapporti Tecnici INGV, 137.

Murru, M., R. Console, G. Falcone, C. Montuori and T. Sgroi (2007). Spatial mapping of the $b$ value at Mount Etna, Italy, using earthquake data recorded from 1999 to 2005, J. Geophys. Res., 112, B12303; doi:10.1029/2006JB004791.

Neri, M., V. Acocella and B. Behncke (2004). The role of the Pernicana Fault System in the spreading of Mount Etna (Italy) during the 2002-2003 eruption, B. Volcanol., 66, 417-430; doi:10.1007/s00445-0030322-X.

Ogata, Y., and K. Katsura (1993). Analysis of temporal and spatial heterogeneity of magnitude frequency distribution inferred from earthquake catalogues, Geophys. J. Int., 113, 727-738.

Patanè, D., E. Privitera, F. Ferrucci and S. Gresta (1994). Seismic activity leading to the 1991-1993 eruption of Mt. Etna and its tectonic implications, Acta Vulcanologica, 4, 47-55.

Patanè, D., and F. Ferrari (1999). ASDP: A PC-based program using a multi-algorithm approach for automatic detection and location of local earthquakes, Phys. Earth Planet. In., 113 (1-4), 57-74.

Patanè, D., and E. Giampiccolo (2004). Faulting processes and earthquake source parameters at Mount Etna: State of the Earth and perspectives, In: A. Bonaccorso, S. Calvari, M. Coltelli, C. Del Negro and S. Falsaperla (eds.), Etna Volcano Laboratory, AGU Geophysical monograph series, 167-189.

Patanè, D., O. Cocina, S. Falsaperla, E. Privitera and S. Spampinato (2004). Mt. Etna Volcano: A Seismological Framework, In: A. Bonaccorso, S. Calvari, M.
Coltelli, C. Del Negro and S. Falsaperla (eds.), Etna Volcano Laboratory, AGU Geophysical monograph series, 147-165.

Rapisarda, S., S. Alparone, L. Cammarata, A. Cannata, D. Contrafatto, F. Ferrari, M. Manni, M. Maturano, V. Milluzzo, P.F. Platania, L. Scuderi, O. Torrisi, L. Zuccarello and S. Gambino (2009). Installazione di 5 stazioni digitali a larga-banda sull'isola di Vulcano: un contributo alla conoscenza della sismicità superficiale della fossa, Quaderni di Geofisica INGV, 67.

Richter, C.F. (1935). An instrumental earthquake magnitude scale, B. Seismol. Soc. Am., 25, 1-32.

Richter, C.F. (1958). Elementary Seismology, Freeman, San Francisco.

Rovida, A., R. Camassi, P. Gasperini and M. Stucchi, eds. (2011). CPTI11, the 2011 version of the Parametric Catalogue of Italian Earthquakes, Milano/ Bologna, http: / / emidius.mi.ingv.it/CPTI; doi: 10. 6092 / INGV.IT-CPTI11.

Rydelek, P.A., and I.S. Sacks (1989). Testing the completeness of earthquake catalogs and the hypothesis of self-similarity, Nature, 337, 251-253.

Scarfi, L., A. Messina and C. Cassisi (2013). Sicily and Southern Calabria focal mechanism database: a valuable tool for the local and regional stress field determination, Annals of Geophysics, 56 (1), D0109; doi:10.4401/ag-6109.

Sicali, S., M. Serafina Barbano, S. D’Amico and R. Azzaro (2014). Characterization of seismicity at Mt. Etna volcano (Italy) by inter-event time distribution, J. Volcanol. Geoth. Res., 270, 1-9.

Traversa, P., and J.R. Grasso (2010). How is Volcano Seismicity Different from Tectonic Seismicity?, B. Seismol. Soc. Am., 100 (4), 1755-1769.

Walter, T.R., V. Acocella, M. Neri and F. Amelung (2005). Feedback processes between magmatic events and flank movement at Mount Etna (Italy) during the 2002-2003 eruption, J. Geophys. Res., 110 (B10), B10205; doi:10.1029/2005jb003688.

Wiemer, S., and M. Wyss (2000). Minimum magnitude of completeness in earthquake catalogs: Examples from Alaska, the Western United States, and Japan, B. Seismol. Soc. Am., 90, 859-869.

Wiemer, S. (2001). A software package to analyze seismicity: ZMAP, Seismol. Res. Lett., 72 (3), 373-382.

Corresponding author: Andrea Ursino,

Istituto Nazionale di Geofisica e Vulcanologia, Osservatorio Etneo, Sezione di Catania, Italy; email: andrea.ursino@ingv.it.

(C) 2015 by the Istituto Nazionale di Geofisica e Vulcanologia. All rights reserved. 


\section{Appendix}

Data distribution of catalogue on the internet

The catalogue is available on the internet at http: / / sismoweb.ct.ingv.it/Catalog_2000-2010 web page of INGV-OE (Earthquake database) and it is updated periodically. After having accessed the main page of the database, the data contained in the catalogue can be viewed and extracted through the 'Catalogue search' page. A main menu is displayed with some choices relating to the area of interest and the depth and magnitude range of the events that the user wishes to consider.

Description of the catalogue fields

ID

Identification number of the event.

YE, MO DA

Year, month and day of the earthquake.

HR, MI, SE

Occurrence time of the earthquake reported as hour, minute and second.

\section{MD}

Duration magnitude.

ML

Local magnitude.

LAT and LONG

The location of the epicentre is expressed in degrees and thousandths as latitude North and longitude East.

\section{DEPSL}

Depth below sea level $(\mathrm{km})$.

\section{DEPGL}

Depth below ground level (km).

\section{$\mathrm{NO}$}

Total number of P- and S-phases used in the earthquake location

\section{RMS}

Root Mean Square of the arrival time-residuals expressed in second and associated with the hypocentral computation.

\section{GAP}

Largest azimuthal separation, in degrees, between stations as seen from the epicenter.
ERZ

Vertical location error $(\mathrm{km})$.

$\mathrm{ERH}$

Horizontal location error $(\mathrm{km})$. 